\title{
Contributions to the histology of the Pontederiaceæ.
}

\author{
EDGAR W. OLIVE.
}

WITH PLATE XVII.

Comparatively little work has been done on the histology of the Pontederiaceæ. The roots have been studied somewhat in a comparative way by M. Treub, L. Morot, F. Hildebrand, S. Schönland, and others. A comprehensive study of the anatomy of water-plants was begun by F. Parlatore, but death prevented the completion of the work. Nine plates, however, were published in $\mathrm{r} 88 \mathrm{I}$. These contain among the drawings of about ninety species of water-plants a few very diagrammatic drawings of two species of Pontederia. No explanation accompanies the plates.

Solms-Laubach has a monograph of the Pontederiaceæ in A. et C. de Candolle's Monographiæ Phanerogamarum; but a short review of this ${ }^{1}$ shows that it is systematic rather than histological. J. Duval Jouve, in I 873 , investigated the diaphragms, or cross-plates, in the air-cavities of Pontederia cordata. E. M. Wilcox, in the Fournal of the Cincinnati Soc. of Nat. Hist., July-Oct., I 893 , has noted a few points in the histology of the same species.

In the botanical laboratories of Wabash College, some studies were made in the spring of 1893 upon the histology of Pontederia crassipes, a cultivated form, and since then a comparative study of all the available members of the order was undertaken and types of other aquatic plants examined. The Pontederiaceæ are aquatic herbs, growing in mud, or shallow water. There' are two genera embracing four species in our northern United States flora, all but one species of which (Heteranthera limosa) are reported in our Indiana flora. ${ }^{2}$ All the four species have been studied, as well as the cultivated Pontederia. In the world's flora there are reported twentythree species and six genera ${ }^{3}$ grouped under this order, principally tropical in their habitat.

Pontederia crassipes Mart. (see fig. I) is an interesting cultivated aquatic, growing rapidly in a basin or vessel of

${ }^{1}$ Botanischer Jahresbericht 11: 622. I883.

${ }^{2}$ Bot. Gaz., 6: Supplement. I88I.

${ }^{3}$ MacMillan, Metaspermæ of Minn. Valley. 1892. 
water and spreading over the surface by means of off-shoots. It has a thick root-stock, and long roots with very many lateral rootlets, so that a light feathery appearance is given to the whole. The roots are colored a dark violet-blue. F. Hildebrand suggests that the probable biological reason for this is to provide immunity from living animals in the water by making the roots less visible to them.

A striking peculiarity is the thick petiole of the leaf. The lower portion is expanded into a resemblance to a pseudobulb, which serves to float the plant. The flowers of P. crassipes, as well as of $P$. cordata L., are violet blue and ephemeral. P. cordata, also, has a thick root-stock. It produces erect long-petioled mostly heart-shaped leaves, and a stem with a single leaf bearing the spike of flowers. ${ }^{4}$

The three species of Heteranthera, $H$. reniformis Ruiz \& Pav., H. limosa Vahl., and H. graminea Vahl. are "creeping, floating, or submerged low herbs, in mud or shallow water, with a I-few-flowered spathe bursting from the sheathing side or base of a petiole." 5

The parts for sectioning were hardened $24-48$ hours in a dehydrating apparatus and afterward imbedded in collodion. Great difficulty was experienced in infiltrating thoroughly with collodion the parts of P. crassipes above the water, the stem, leaf, etc., presumably on account of the floating tissues being so repellent to liquids. Especially was this difficulty found with every part of the leaf tissues, parts of which were cutindifficulty loose aerating tissues of the root present no such Most interestino any of the tissues of the other species. brought out. The root of P. crassipes presents a beautiful structure. verytip of thery large and is organically connected with the ale ${ }^{6}$ says that the only, being free at its upper end (fig. 3). GoodPontederia, this sort of a cap occurs in several species of centimeter. the largest roots caps of P. crassipes, however, enveloped section of the for $2.5^{\mathrm{cm}}$ or even more. A median longias well as the root-tip shows well the connection of the cap as the structure of the tip itself. Hæmatoxylin

\footnotetext{
'Gray's Manual, 536. 'Phay's Manual, 536.
'Phiological Bot., Io8.
} 
brought out a marked differentiation just without the central cylinder, in the pericambium. At regular intervals, certain small groups of cells peripheral to the central cylinder stained a much darker blue than the surrounding cells. From their position it was judged these were the nascent tissues of the lateral rootlets, the darker staining indicating their greater activity. The mode of formation and development of the lateral roots from the mother root can be easily followed. Longisections of the rootlet coming off from various sections of the root were secured. These show the rootlet branching from the pericambium and organically connected with the central cylinder only, for a space surrounds it and separates it from the endodermis, cortex and epidermis.

Back from the tip at varying distances in different roots of the same length, but averaging about $1.5^{\mathrm{cm}}$, were noticed the beginnings of the large air-cavities. A cross-section shows the plerome cylinder surrounded by a sheath of thin-walled cells. Just without this endodermis are about six or seven rows of very regular cylindrical cells (fig. 2) forming loose tissue, with large intercellular spaces. Outside of these, between the cells of the cortex proper, occur the radiating aircavities of varying width, traversing the length of the root.

The coloring matter of the root and root-stock, anthocyanin, imparts a dark-blue color, except for an inch or more back of the tip. It is in solution in the cell-sap of the epidermal cells only; is soluble in alcohol and is turned red by dilute acids.

The running stem bears an off-shoot at its distal end. It has aerating spaces particularly large and abundant near its periphery. The closed collateral bundles are but few in this loose region. By far the greater number are aggregated in the center of the stem, forming in mass a cylinder. The root-stock has a structure somewhat similar to that of the stem. Bundles of raphides are very abundant, especially toward the periphery, outside of the cylindrical aggregation of bundles. There was no evidence of starch being stored in the root-stock.

The leaf shows perhaps the most interesting histological structure. When the inflated petiole is cut through, large hexagonal cavities 0. $5-2^{\mathrm{mm}}$ in diameter are seen(fig. 4 ). The shining cutinized partitions are plainly visible. This loose tissue is almost impervious to water. A section placed in water shows a great deal of air imprisoned in the cavities. This inflated petiole refused to be infiltrated. 
The cross-partitions, or diaphragms, are horizontal or oblique and are composed of polygonal cells, with interstitial air-spaces at the angles leading from one chamber to another. The cell walls in some of the partitions are very thick. According to De Bary " "air-passages in internodes, petioles, and leaves of most monocots are partitioned by diaphragms," or "stellate tissue," as it is frequently called. De Bary furthermore makes the general statement that Pontederia has diaphragms composed of many-armed cells "forming a plate with wide lacunæ." In the plates of P. crassipes, "interstitial spaces" is the more correct term for the openings between the cells, because they are of much smaller volume than the surrounding cells. True lacunar cavities occur in the diaphragms of P. cordata, however, while those of Heteranthera limosa and $\mathrm{H}$. reniformis are small like those of $\mathrm{P}$. crassipes. The cells of the diaphragm each have well-defined nuclei and granular protoplasmic contents, with a few starch grains. These diaphragms probably serve several purposes. Duval Jouve suggests that besides the function of allowing the passage of air, they have the office of support points for the cross-running 8 fibrovascular bundles. No transverse bundles, however, were noticed in P. crassipes, while in P. corpheral passages do they occur, those of the central cavity being free from them. Probably one of their principal functions is to support the surrounding parenchyma tissue and to prevent the air-passages from collapsing.

A cross section of the leaf of P. crassipes shows how admirably lightness is secured. A large air-passage usually with the latter. Stomates are abundant on both sides of the leaves and on the petioles of all the species except Heteranthera graminea, the latter being submerged. The epidermal
cells of each are those of P are somewhat thin-walled with the exception of outer walls. cordata, which have minute tubercles on their The

species. The vascular bundles are very similar in all the enchyma They are surrounded usually by one layer of para few scleren with a large amount of bast in the phloëm and sclerenchyma cells opposite. Mr. Wilcox says that

\footnotetext{
${ }^{7}$ Comp. Anat., 217.
"Review in Bot. Jahres. 1: 196.
} 
there are in P. cordata "peculiar starch cells" on each side of the fibro-vascular bundle. The "specialized cells," as he further designates them, were noticed in the petiole and leafbundles of P. crassipes just without the xylem portion of the bundle on either side, also an abundance of grains was seen in the larger parenchyma cells of the sheath proper (see fig. 4.). Also in P. cordata these cells were noted, with little starch or none in the larger cells surrounding. Sachs ${ }^{9}$ says that "the reservoirs of reserve materials or organs of assimilation . . are chiefly in that layer of parenchyma which immediately surrounds the vascular bundle." This Sachs long ago introduced into physiology as the "endodermis" and called it the "starch-bearing layer." As these "specialized cells" are part of the parenchyma cells of the "starch-bearing layer" of Sachs, one is hardly justified in designating these cells "peculiar starch cells," when their presence is the rule in all bundles. In Heteranthera limosa starch is very abundant in stem, petiole, and leaf, particularly in the parenchyma bundle sheath and the loose cells immediately about the bundle on both sides of the xylem, also in the cells of the diaphragms.

These conditions illustrate an important physiological fact, that the store-houses of food are near the highways, where it is most easily accessible. The distribution of reserve food in aquatics and the arrangement of the aerating organs is a subject of great importance. A comprehensive view of the varying conditions in aquatic plants will throw a great deal of light upon many interesting physiological problems in the life history and development of these interesting groups of plants.

In the diaphragms of $\mathrm{P}$. cordata and $\mathrm{P}$. crassipes are found crystal sacs containing raphides, projecting upward or downward into the cavities. Besides there are other sacs of a spindle-like shape (fig. 5.), with their longer axes placed at right angles to the diaphragm and with their middle inserted in it, so that the ends project upward and downward into the space. Each of these contains a spear-like crystal of calcium oxalate, pointed at both ends. In P. crassipes, this long kind of crystal is not so abundant in the cross-plates examined. In P. cordata, the sac attains a length of more than three times the thickness of the diaphragm. De Bary ${ }^{10}$

\footnotetext{
${ }^{9} \mathrm{Physiology}, 358$.

10 Comparative Anatomy, 220.
} 
refers to Meyen for authority for the statement that the "membrane of the sac covering the ends of the crystal ceases to be apparent, so that the latter seems to protrude freely into the air-space." None in the diaphragms of the P. cordata studied presented this phenomenon. On the contrary, it was found that all were in thick-walled sacs. In all probability, the unusual thickness of the walls partly explains the long resistance to the action of acids. Concentrated $\mathrm{HCl}$ applied to the section of the diaphragm slowly dissolves the raphides in one to two minutes, while the lance-shaped crystals were not completely dissolved for $I \frac{1}{2}$ hours or more, leaving the thick wall of the sac but slightly shrunken. In Heteranthera limosa, no long crystals were observed. There was, however, an abundance of raphides, especially in the small peripheral cavities of the petiole.

There was also present in most of the cross-plates of all the five species, but most abundant in P. cordata, a reddishbrown secretion in ellipsoid or dumb-bell shaped cells with very thick walls, scattered in few numbers among the stellate cells (figs. 5 and 6). Ether acts very slowly on this secretion. Preliminary experiments led to the belief that it was a gum. But, in $24-48$ hours, the section left in ether showed a yellowish-brown color in the cells immediately surrounding the ellipsoidal cell, intimating the slow dissolution of the contents. Benzine acted much more rapidly in its dissolution. In all probability, the substance is a fatty oil, though
there is room for doubt.

Among the upper row of long palisade cells of the leaf of P. cordata are many others of similar shape containing a yelbetween the many stomates, as can be seen in a thin tangential section. Probably also in P. crassipes and H. graminea,
this substan this substance occurs sparingly. Nothing was positively de-
termined termined as to its composition.

In the older stellate tissue of P. cordata, a marked peculiarity was noticed in the walls where the arms of adjoining cells met. Under high power frequently were seen one to a the two served cells (fig. 6). In cross section, small pits were obwalls, concent a narrow partition. In testing for cellulose the stellatentrated sulphuric acid shrunk the protoplasm in 
ning from the mass into each ray of the cell. In many cases the thread held fast through the pore to that of the adjoining cell - a beautiful exposition of continuity of protoplasm.

The presence of active nuclei in the cells of the diaphragm and of starch in some, and the continuity of the protoplasm in the cells, is suggestive of these cross-plates serving a far more important function than the mere mechanical one of support. These facts indicate rather a close connection with the centers of vital activity in the plant.

New light may be thrown by such a suggestion upon the presence and regular occurrence of diaphragms in this group of plants. Some physiological experiments may further point out the real functions. It is expected that a careful study will be made of the structure of plants of allied groups and the true relationships of aquatics sought.

\section{BiBLIOGRAPHY.}

I. J.DUVAL Jouve, Diaphragmes vasculiféres des monocotylédones aquatiques. Mémoires de l'Académie de Montpellier, 8: $157-176$. pl. 8. 1873 .

2. Meyen, Phytotomie, pl.5. fig. 6 .

3. VAN TIEghem, Ann. Sci. Nat., V. 6: 132.

4. M. TREUB, Le méristème primitif de la racine dans les monocotylédons. Musée Bot. de Leide, 2:-.1876.

5. F. ParLatore, Tavole per una anatomia delle piante aquatische. Florence, 1881. Published by T. Caruel.

6. F. Hildebrand, Berichte der Deutschen Bot. Gesell. 1: xxvir-xxix. 1883.

7. L. Morot, Recherches sur la péricyclus ou couche périphérique du cylindre central chez les pbanérogames. Ann. Sci. Nat., VI. 20: 217-309. 1884.

8. S. SchönLAND, The apical meristem in the roots of the Pontederiacex. Annals of Bot. 1: 179-182, I885.

9. S. Schönland, Engler and Prantl, Nat. Pflanzenfam., II. Abth.4. 70. 1887.

Io. L. Petit, Nouvelles recherches sur le pétiole des phanérogames. Actes

S. L. Bordeaux-:I-50. I889,

II. E. M. Wincox, The histology of the stem of Pontederia cordata, Jour. Cincinnati Soc. of Nat. Hist., July-Oct., 1893.

Wabash College, Crawerdsville, Ind.

\section{Explanation of Plate XVII.}

Fig. I. A young plant of P. crassipes, showing an off-shoot. $X_{1 / 4}^{1 /}-$ Fig. $^{2}$. Transection of root of $\mathrm{P}$. crassipes. $\times 140 .-$ Fig. 3. Longisection of root-tip of P. crassipes, showing cap and origin of lateral rootlets. $\times 55 .-F i g .4$. Trait section of inflated petiole of $\mathrm{P}$. crassipes; $a$, diaphragm, with starch in the cells;,$b$, starch grains in bundle sheath. $\times 55$. - Fig. 5 . Transection of diaphragm of P. cordata; $a$, side partition of air-cavity, showing the attapbment of the diaphragm; $b$, a spindle-shaped crystal in its sac; $c$, a bundle of raptides; $d$, two pits in the wall between two cells; $e$, a secretion of a fatty ill, showing manner of insertion among the cells of the diaphragm. $\times 35^{\circ}$. - Fig. $b_{\text {, }}$ Surface view of a portion of a diaphragm of $\mathrm{P}$. cordata: $a$, an air-passage, a pit in the wall separating two cells; $c$, cell containing fatty oil. $\times 350$ 7. Transection of leaf of P. cordata. Upper portion of the section, showion the large cells among the palisade cells, the former filled with some secretion $\times 350$. 


\section{$2 \mathrm{BHL}$ Biodiversity Heritage Library}

Olive, Edgar W . 1894. "Contributions to the Histology of the Pontederiaceæ." Botanical gazette 19(5), 178-184. https://doi.org/10.1086/327042.

View This Item Online: https://www.biodiversitylibrary.org/item/93164

DOI: https://doi.org/10.1086/327042

Permalink: https://www.biodiversitylibrary.org/partpdf/222360

\section{Holding Institution}

Missouri Botanical Garden, Peter H. Raven Library

\section{Sponsored by}

Missouri Botanical Garden

\section{Copyright \& Reuse}

Copyright Status: Public domain. The BHL considers that this work is no longer under copyright protection.

This document was created from content at the Biodiversity Heritage Library, the world's largest open access digital library for biodiversity literature and archives. Visit BHL at https://www.biodiversitylibrary.org. 